\title{
Greener and Fairer: A Progressive Environmental Tax Reform for Spain
}

\author{
CHRISTOPH BÖHRINGER, ${ }^{a}$ XAQUÍN GARCÍA-MUROS, ${ }^{\text {b,c }}$ and MIKEL GONZÁLEZ-EGUINO ${ }^{\text {b,d }}$
}

\begin{abstract}
Environmental externalities call for the use of environmental taxes to get prices right and thereby reduce environmental pressures. To date, however, the Spanish government makes only limited use of environmental taxes. One major reason for the policy reluctance are concerns on the regressive impacts of environmental taxes. We argue that policy can hedge against these concerns by means of revenue recycling. More specifically, we assess the impacts of a green tax reform where additional revenues are redistributed lump-sum to Spanish bousebolds on an equal-per-capita basis. Based on quantitative evidence from coupled microsimulation and computable equilibrium analyses we find that such a green tax reform leads to a substantial reduction in harmful emissions while having a progressive impact.
\end{abstract}

Keywords: Environmental tax reform, household incidence, computable general equilibrium, microsimulation

\section{* 1. INTRODUCTION}

The use of taxes to correct environmental externalities is a standard public finance proposition rooted in the seminal work of Pigou roughly one hundred years ago (Pigou 1920). Apart from protecting the environment as a public good and making the polluters pay for damages, environmental taxes raise revenues that can be used to reduce existing tax distortions. Such green tax reforms may then provide an opportunity to earn a double (or even triple) dividend (Pearce 1991; Repetto 1992). They do not only improve the environment - the first dividend. They may also contribute to a reduction of the overall excess burden of the tax system - the second dividend — and may help to alleviate involuntary unemployment — the third dividend. ${ }^{1}$

Given increasing environmental pressures from local air pollution but also global externalities such as greenhouse gas emissions, international organizations - notably, the European Commission (EC 2011), the International Monetary Fund (IMF 2013), and the OECD

1. The potential effects of green tax reforms have been investigated in a large number of theoretical and applied papers; for early surveys see Goulder (1995) and Bovenberg (1999) — a more recent meta-regression analysis of the double-dividend hypothesis is provided by Anger et al. (2010).

\footnotetext{
${ }^{a}$ Corresponding author. Department of Economics, University of Oldenburg (Germany). E-mail: christoph.boehringer@ uni-oldenburg.de.

${ }^{\mathrm{b}}$ Basque Centre for Climate Change (BC3), Leioa (Spain).

${ }^{c}$ MIT Joint Program on the Science and Policy of Global Change, Boston (USA).

${ }^{\mathrm{d}}$ University of the Basque Country (UPV/EHU), Bilbao (Spain).
} 
(OECD 2015) — have highlighted the importance of boosting environmental taxes in modern taxation systems.

While environmental taxes meanwhile play a more prominent role in the tax system of various OECD countries (OECD 2017), policy makers in Spain so far have been rather reluctant to make more comprehensive use of environmental taxes (Gago and Labandeira 2014). A few additional environmental taxes were introduced in 2012, but according to the Lagares Report (Informe Lagares 2014), these measures remained "fragmentary and limited". ${ }^{2}$ In 2015, the percentage of tax revenue attributable to energy/environmental taxes ${ }^{3}$ was $1.8 \%$ of GDP, compared to $2.4 \%$ for the EU-28 average putting Spain to fourth-last in the EU-28 with a substantial leeway to top-ranked countries such as Denmark, whose environmental tax revenue is $4 \%$ of GDP (Eurostat 2017).

Gago and Labandeira (2014) discuss three major reasons for this lack of political support in Spain: 1) concerns on regressive impacts; 2) the threat of adverse competitiveness effects which could lower the overall performance of the Spanish economy; and 3) the potential instability of environmental tax revenues as they are targeted to reduce their source.

Here we focus on regressivity concerns as an important policy caveat against environmental taxation. The rationale on the regressivity concerns of environmental taxation is straightforward. Taxes on energy or energy-related pollutants such as $\mathrm{CO}_{2}, \mathrm{NO}_{\mathrm{x}}$, or $\mathrm{SO}_{2}$ raise consumer prices for energy goods such as electricity, natural gas, heating oil or gasoline. Since these goods constitute a larger share of the budget for poorer households than for richer households, environmental taxes tend to be regressive, in the sense that extra tax payments represent a higher percentage of income for poorer households than for the richer households.

The empirical literature on distributional impacts by and large confirms the regressive effects of environmental taxes (for meta-analyses see e.g. OECD 1995, Speck 1999, Speck et al. 2006, Leipprand et al. 2007, Peter et al. 2007, Kosonen 2012 or Gago et al. 2014). The European Environmental Agency (EEA 2011) provides a comprehensive literature survey on the implications of environmental taxation for various European countries. Although most of the reviewed studies find regressivity, several factors could mitigate or even offset the regressivity, such as the specific design of fuel (energy) taxation, spillover effects to factor prices or the use of additional tax revenues. Energy taxes on households' heating fuels are identified as clearly regressive. But taxes on motor fuels (oil, diesel) tend to hit low income groups relatively less than high income groups for the case that high income groups tend to spend more on transportation fuels (as a share of their income) than low income groups. ${ }^{4}$ Moreover, environmental taxes do not only affect the prices of consumer goods, but also can affect sources of income, such as wages and returns to capital. Many (partial equilibrium) studies on the incidence of taxation focus on the expenditure side and miss the (general equilibrium) feedback effects on factor incomes. Finally, the recycling of additional revenues can drastically affect the overall distribu-

2. The report by a committee of Experts for the Reform of the Spanish Tax System (known as the Lagares Report) was issued at the request of the Spanish government and submitted in August 2014. It proposed numerous measures for modernizing the Spanish tax system including the more comprehensive use of environmental taxes. The report states that green tax reforms are "unfinished business" in Spain (see also González-Eguino 2011 or Labandeira and Linares 2013).

3. Tax revenues as recorded by Eurostat are divided into energy taxes (including taxes on $\mathrm{CO}_{2}$ and revenues from the sale/ purchase of $\mathrm{CO}_{2}$ emission permits and taxes on all energy-related goods, including fuels), transport taxes (including those relating to the purchase and use of means of transport), pollution taxes (including those on emissions of pollutants such as $\mathrm{NO}_{\mathrm{x}}$ and $\mathrm{SO}_{2}$ into the air and water, pesticides, fertilisers and waste management) and taxes on resources (including mineral extraction, fishing and wood).

4. For example, progressive impacts of transport taxes are identified for Poland (Kiuila and Sieszynkski 2003) or Spain (Labandeira and Labeaga 1999). 
tional consequences either enforcing or offsetting the direct incidence of environmental taxes. For example, one can enforce the regressive impacts of heating fuel taxation by combining it with a regressive use of revenues (such as a cut in taxes on capital); alternatively, one can opt for a progressive use of revenues (such as lump-sum transfers).

In this paper, we make the case for a green tax reform in Spain where revenues are redistributed lump-sum to Spanish households. Our tax reform reflects policy-relevant pressures towards new environmental taxes on fuels, local air pollutants and $\mathrm{CO}_{2}$ emissions: 1) a tax on $\mathrm{CO}_{2}$ (€40/ton) in all sectors (except transport) which are not covered by the EU emissions trading system; 2) tax increases on fossil fuels to bring them up to the European average (1.5\% of GDP); and 3) taxes on air pollutants $\left(\mathrm{NO}_{\mathrm{X}}\right.$ as well as $\mathrm{SO}_{2}$ emissions at $€ 1000 /$ ton) throughout the economy. On the revenue-recycling side, additional taxes are rebated lumpsum per-capita to private households. ${ }^{5}$

For our quantitative impact assessment of the proposed tax reform, we combine a multi-sector computable general equilibrium (CGE) model of the Spanish economy with a microsimulation (MS) analysis of Spanish households. We find that the tax reform will entail significant reductions in emissions of $\mathrm{CO}_{2}(10 \%), \mathrm{NO}_{\mathrm{X}}(13 \%)$ and $\mathrm{SO}_{2}(20 \%)$. Additional environmental taxes will yield revenues-estimated at $€ 7.3$ billion per year-that accommodate an annual $€ 400$ lump-sum transfer to Spanish households. Lump-sum recycling renders the green tax reform clearly progressive, providing first- and second-income quintiles with increases in average spending power of $€ 166$ and $€ 65$ per year, respectively. Households below the poverty line would even see their average spending power increased by $€ 174$. If we cast fairness preferences into a social welfare function with an egalitarian perspective, the tax reform improves social welfare-rendering the Spanish tax system greener and fairer.

Our contribution to the applied analysis of environmental taxation is twofold. First, our results can vitalize the policy debate on green tax reforms in Spain pointing to the crucial role of lump-sum revenue-recycling as a response to regressivity concerns. Second, we base our analysis on a powerful combination of computable general equilibrium and microsimulation models to capture key drivers of tax incidence in a consistent manner, thereby increasing the robustness of simulation results and policy conclusions.

The remainder of this the paper is organized as follows. Section 2 features a brief summary of our method of assessment and the underlying data. Section 3 provides a description of the environmental tax reform proposed. Section 4 presents our quantitative impact assessment. Section 5 concludes.

\section{* 2. METHOD AND DATA OF ASSESSMENT $\not$}

For our quantitative impact assessment, we combine a computable general equilibrium (CGE) model of the Spanish economy with a detailed microsimulation (MS) model of income-expenditure patterns across households. The advantage of the CGE-MS combination is that we can analyze the economy-wide adjustment to policy reforms and are at the same time able to provide a very detailed perspective on the policy incidence across households. Our integrated modelling framework does not only feature a rich representation of household

\footnotetext{
5. In the policy debate, lump-sum recycling of environmental tax revenues is sometimes referred to as the eco-bonus concept. In essence, this concept combines environmental taxes with per-capita refunds. The amount of the eco-bonus is thereby independent from the energy consumption of the individual recipients.
} 
heterogeneity but accounts for important inter-sectoral linkages and price-dependent market feedbacks across the whole economy.

\subsection{Computable general equilibrium (CGE) model}

Our CGE model shares the core logic of canonical multi-sector computable general equilibrium models (for a detailed algebraic formulation of the core logic see e.g. Böhringer et al. 2015). Decisions about the allocation of resources are decentralized and the representation of behavior by consumers and firms in the model follows the standard microeconomic optimization framework. Consumers maximize welfare through private consumption subject to a budget constraint. Producers combine intermediate inputs and primary factors (labor, capital, sector-specific resources) at least cost for given technology. By default, labor and capital are treated mobile across sectors while specific resources are tied to sectors. Preferences and technological constraints are described through nested constant-elasticity-of-substitution (CES) functions that capture demand and supply responses to changes in relative prices.

Production of commodities other than fossil fuels is captured by nested three-level CES cost functions describing the price-dependent use of capital, labor, energy and material in production. At the top level, a CES composite of intermediate material demand trades off with an aggregate of energy, capital and labor. At the second level, a CES function describes the possibilities of substitution between the intermediate demand for the energy aggregate and a value-added composite of labor and capital. Finally, at the third level, a CES function captures the possibilities of capital and labor substitution within the value-added composite, while different energy inputs (coal, gas, oil and electricity) enter the energy composite subject to a CES. In the production of fossil fuels, all inputs except the sector-specific fossil fuel resource are aggregated in fixed proportions; this aggregate trades off with the sector-specific fossil fuel resource at a CES.

Final demand for consumption in the CGE model is determined by a representative household, which maximizes utility subject to a budget constraint with fixed investment (constant savings). ${ }^{6}$ The representative agent receives income from three primary factors: labor, capital and fossil fuel resources (coal, gas and crude oil). Final demand for consumption is given as a CES aggregate of composite non-energy consumption and composite energy consumption. Both the non-energy consumption composite and the energy consumption composite are in themselves CES functions of disaggregate non-energy and energy commodities.

To reflect involuntary unemployment, we adopt a standard wage curve formulation which reflects empirical evidence on the inverse relationship between the level of wages and the rate of unemployment (Blanchflower and Oswald 1995).

Bilateral trade follows the Armington (1969) approach of product heterogeneity, where domestic and foreign goods are distinguished by their origins. All goods used on the domestic market in intermediate and final demand correspond to a CES composite that combines domestically produced goods and the goods imported from other regions. A balance of payment

6. In our static model analysis, we abstain from tracking impacts of green tax reforms on investment and savings behaviour of households. Ultimately, an adequate representation of investment and savings behaviour would call for an intertemporal model with rational expectations by individual households which is beyond the scope of our current integrated CGE-MS framework where we incorporate lots of household details. 
constraint incorporates the base-year trade surplus (deficit) which is warranted through an endogenous real exchange rate. ${ }^{7}$

Finally, the CGE model incorporates emissions of $\mathrm{CO}_{2}, \mathrm{NO}_{\mathrm{X}}$ and $\mathrm{SO}_{2}$ via coefficients associated with the use of fossil fuels. Emission abatement can take place by fuel switching (inter-fuel substitution) or fuel savings (either by fuel-non-fuel substitution or by a scale reduction of production and final demand activities).

\subsection{Microsimulation (MS) model}

The MS model captures the economic behavior of consumers and provides a detailed picture of the substitution effects in consumption following price changes (driven by price elasticities and income elasticities). Consumer demand is estimated using the "Almost Ideal Demand System" (AIDS) introduced by Deaton and Muelbauer (1980), the main advantage of which is that it permits a linear approximation of a flexible demand system. The AIDS satisfies the axioms of the consumer theory and does not impose constraints on the utility function. The log-linear approximation (LAIDS) of demand functions is as follows:

$$
w_{i}=\alpha_{i}+\sum_{j=1}^{n} \gamma_{i j} \ln p_{j}+\beta_{i} \ln (Y / \tilde{p})+t+d+e_{i}
$$

where:

$w_{i}$ represents the budget share associated with good i for a particular household, $\alpha_{i}$ is a constant,

$\gamma_{i j}$ is the slope coefficient associated with the $\mathrm{j}$ good in the i share equation,

$p_{j}$ is the price of good $\mathbf{j}$,

$\beta_{i}$ is the slope coefficient for real income,

$\tilde{p}$ stands for the geometric Stone price index ${ }^{8}$,

$Y$ is household income (hence, $\mathrm{Y} / \tilde{p}$ represents real income),

$t$ denotes the time trend variable,

$d$ is a set of dummy variables that control: the type of household, ${ }^{9}$ the region where the household is located in terms of the seven NUTS 1 regions in Spain, ${ }^{10}$ whether the household is living in a private home, the number of rooms in the household, the age of the breadwinner, whether the breadwinner is unemployed or retired, the number of active members in the household, whether the house is equipped with heating and the type of house, ${ }^{11}$ and

$e_{i}$ denotes the error term.

7. The balance-of-payment constraint at base-year levels reflects no change in net indebtedness of Spain vis-à-vis the rest of the world which is a prerequisite of coherent welfare analysis for domestic policy shocks such as the green tax reforms investigated in this paper.

8. The Stone price index is defined as follows: $\log \tilde{p}=\sum_{i=1}^{n} w_{i} \ln p_{i}$.

9. The household categories used in our estimation are the following: adults alone; couple without children; couple with children; single-parent households; and the composite of other households.

10. According to the Nomenclature of Territorial Units for Statistics at the first level (NUTS 1) there are seven regions in Spain: North West (Galicia, Asturias, Cantabria), North East (Basque Community, Navarre, La Rioja, Aragon), Community of Madrid (Community of Madrid), Centre (Castile and León, Castile-La Mancha, Extremadura), East (Catalonia, Valencian Community, Balearic Islands), South (Andalusia, Region of Murcia, Ceuta, Melilla) and Canary Islands (Canary Islands).

11. The house categories used are the following: luxury, high class in urban area, middle class in urban area, low class in urban area, rural industrial, rural fishing, and rural agriculture. 
The adding-up and homogeneity restrictions of equation [1] are as follows:

$$
\begin{aligned}
& \sum_{i=1}^{n} \alpha_{i}=1 \\
& \sum_{j=1}^{n} \gamma_{i j}=0 \\
& \sum_{i=1}^{n} \beta_{i}=0
\end{aligned}
$$

and the symmetry condition is given by:

$$
\gamma_{i j}=\gamma_{j i}
$$

Finally, the sum of $w_{i}$ must satisfy:

$$
\sum_{\mathrm{i}=1}^{n} w_{\mathrm{i}}=1
$$

We estimate demands for nine consumption categories including food, housing, durables, heat, electricity, fuel, transport, leisure and education, and a composite of other products. Since the AIDS model is made up of a system of dependent equations, the share equation regarding the composite of other products is dropped to overcome singularity problems. Annex A reports our regression results.

\subsection{Coupling of CGE and MS models}

The CGE and MS models are linked iteratively based on the decomposition method by Rutherford and Tarr (2008). We first run the CGE model which represents households by one single representative household in order to evaluate policy impacts on prices for consumer goods and production factors. The MS model then takes these prices as inputs and calculates household income and household consumption at the given prices. Based on the MS numbers, the representative household in the CGE model is recalibrated to reproduce aggregate consumption at given prices. With the recalibrated expenditure function of the representative household, the CGE model is solved again and then hands over commodity and factor prices for the next iteration round to the MS model. By repeatedly resolving the CGE and MS models, the two models converge towards an overall consistent solution. Thus, the coupled models produce identical results, as would a stand-alone CGE model with all heterogeneous households. The combined CGE-MS approach has the advantage of numerical tractability and reduced CPU time given the large number of households in income-expenditure surveys.

\subsection{Data}

The CGE model is calibrated to Spanish input-output (IO) data for 2014 (INE 2018a). Output per sector is linked to household consumption in terms of consumer spending categories using a conversion matrix. Cross-price substitution elasticities in production other than of fossil fuels are based on empirical estimates by Koesler and Schymura (2015). The elasticities of substitution in fossil fuel production sectors are calibrated to match exogenous estimates of fossil fuel supply elasticities (Graham et al. 1999; Krichene 2002; Ringlund et al. 2008). The $\mathrm{CO}_{2}, \mathrm{NO}_{\mathrm{X}}$, and $\mathrm{SO}_{2}$ emissions from fossil fuels are calculated using physical energy data and air emissions accounts for Spain in 2014 compiled by Eurostat (Eurostat 2018). 
The database used to estimate the microsimulation model is the Spanish household budget survey (EPF-see INE 2018b). The EPF is a survey representative of the population of Spain, which collects annual information on the consumption patterns and various socio-economic characteristics for around 20,000 households. For estimating the LAIDS, we use data from 2006 to 2013 whereas the microsimulation is operated for 2014 data in consistency with the base-year for the CGE simulations. Income sources for households are based on data from the Spanish living conditions survey (ECV). To consolidate data sources, we scale the spending and demand data from the EPF in line with the data aggregated from the IO table; similarly, we scale the household revenue data. Due to missing data on savings by households in the EPF, we distribute the aggregated savings reported in the IO data across households according to the weight of income from capital in their respective revenues.

\section{* 3. ENVIRONMENTAL TAXATION AND REVENUE RECYCLING OPTIONS}

In our quantitative impact assessment of green tax reforms, we address alternative policy-relevant proposals for implementing additional environmental taxes and recycling green tax revenues. On the taxation side, proposals involve new environmental taxes on fuels, local air pollutants and $\mathrm{CO}_{2}$ emissions. On the recycling side, options include direct rebates to households and reductions in social security contributions beyond the default case of leaving additional income to the public budget.

\subsection{Tax on vehicle fuels}

Given the environmental pressure from traffic, the Lagares Report suggests to increase fuel taxes - especially for diesel fuel. Likewise, the International Energy Agency (IEA 2015) is supportive of higher fuel taxes in Spain—not at least because of tax harmonization as fuel taxes in Spain are below the level of the European average. Here we simulate a tax on vehicle fuels to achieve the average revenues share across EU Member States of the EU, i.e. 1.5\% of GDP.

\subsection{Tax on $\mathrm{SO}_{2}$ and $\mathrm{NO}_{\mathrm{X}}$ emissions}

Sulphur dioxide $\left(\mathrm{SO}_{2}\right)$ and oxides of nitrogen $\left(\mathrm{NO}_{\mathrm{X}}\right)$ are the main causes of harmful air pollution. According to the World Health Organisation (WHO and OECD 2015), air pollution caused 14,000 early deaths in Spain in 2010. The WHO further states that the impact of these deaths resulted in economic losses equivalent to $2.5 \%$ of GDP. The Lagares Report suggests a tax on non- $\mathrm{CO}_{2}$ emissions such as $\mathrm{SO}_{2}$ and $\mathrm{NO}_{\mathrm{X}}$ which is harmonized nationwide. Thus, we simulate a tax on $\mathrm{NO}_{\mathrm{x}}$ and $\mathrm{SO}_{2}$ applied to all sectors of the Spanish economy. Estimates for the external cost of $\mathrm{SO}_{2}$ and $\mathrm{NO}_{\mathrm{X}}$ for Spain range between $€ 5,000$ up to $€ 15,000$ per ton (Holland et al. 2005 or Markandya et al. 2010). However, the taxes on these pollutants introduced to date in EU countries are well below those figures ranging around $€ 1,000$ per ton (Labandeira and Linares 2013), which we take as the reference value for our simulation analysis. ${ }^{12}$

12. Spain so far stands out for being a laggard rather than a forerunner in environmental taxation (Informe Lagares 2014 or Eurostat 2017). To keep with policy realism, it makes thus sense to adopt the tax rates on local air pollutants of forerunner EU countries as a reference value rather than setting tax rates at (much higher) external cost estimates. 


\subsection{Tax on $\mathrm{CO}_{2}$ emissions in non-ETS sectors}

$\mathrm{CO}_{2}$ emissions are a key driver of global warming. To date, the EU controls $\mathrm{CO}_{2}$ emissions within the European Union Emissions Trading System (ETS) which covers only installations in energy-intensive sectors. For the remaining $\mathrm{CO}_{2}$ emissions in non-ETS sectors, the EU Member States have committed themselves to achieve a 10\% reduction on average by 2020 as compared to 2005 emission levels. Spain's individual commitment is actually at the EU average of $10 \%$. For our simulation analysis, we depict a $\mathrm{CO}_{2}$ tax on non-ETS sectors of $€ 40$ per ton. This tax is in line with recent IPCC ${ }^{13}$ recommendations for a global $\mathrm{CO}_{2}$ price of $\$ 44$ per ton in 2020 (as part of a dynamic price path to meet the $2^{\circ} \mathrm{C}$ temperature target envisaged by the world community in the Paris Agreement).

\subsection{Rebates on revenues}

The extensive literature on double dividends from green tax reforms has examined various ways of returning revenues from environmental taxes to the economic system, such as revenue-neutral reductions in income taxes, social security contributions or VAT taxes (for Spain see previous revenue-recycling options suggested by Labandeira et al. 2004, Manresa 2005, or Markandya et al. 2013). While all of these recycling options may stimulate positive economic effects, they are less visible to the individual households as compared to direct tax rebates by which all citizens regardless of their status receive an explicit monetary transfer. Such lumpsum refunding of green tax revenues, which is sometimes referred to as 'eco-bonus', has been discussed by the Green Party in Germany and was, for example, introduced in Switzerland in 2008. The political economy argument in favor of direct tax rebates is its higher visibility, perceived equity and social acceptability (EEA 2011). In this vein, we simulate a lump-sum rebate for each household. Alternatively, we investigate the effects of a proportional reduction in social security contributions as an indirect recycling option.

Table 1 summarizes the set of six tax policy scenarios covered by our simulation analysis. On the left-hand side, we consider the imposition of environmental taxes without revenue recycling - in this case, additional revenues remain in the public budget and lead to increased public spending. On the right-hand side, we consider revenue-neutral tax reforms where additional tax revenues are either rebated lump-sum or used for reductions in social security contributions.

\section{* 4. SIMULATION RESULTS}

We discuss the simulation results for the six aforementioned scenarios in three sections: 1) environmental and macroeconomic impacts; 2) incidence on household groups; and 3) social welfare effects. If not stated differently, results are reported as percentage changes from the business-as-usual $(\mathrm{BaU})$ situation absent any additional policy measures.

\subsection{Emission reductions and GDP impacts}

The main objective of environmental taxes is to reduce harmful emissions. Figure 1 indicates that the scenarios proposed succeed in this respect as the implementation of additional

13. See the database of the long-term scenarios reviewed in the Fifth Assessment Report (AR5) of Working Group III of the Intergovernmental Panel on Climate Change (IPCC): https://tntcat.iiasa.ac.at/AR5DB. 


\section{TABLE 1}

Summary of tax policy scenarios (acronym for each scenario in bold).

\begin{tabular}{|c|c|}
\hline \multicolumn{2}{|r|}{ Tax policies without revenue recycling } \\
\hline $\mathrm{Tax}_{-} \mathrm{CO}_{2}$ & $€ 40 /$ ton of $\mathrm{CO}_{2}$ in non-ETS sectors \\
\hline $\mathrm{Tax}_{-} \mathrm{NO}_{X}, \mathrm{SO}_{2}$ & Tax on local pollutants $\left(\mathrm{NO}_{\mathrm{X}}\right.$ and $\left.\mathrm{SO}_{2}\right)$ equivalent to $€ 1,000 /$ ton \\
\hline Tax_Fuel & Increase of vehicle fuel up to the EU average of $1.5 \%$ revenues in GDP \\
\hline Tax_All & All the above taxes \\
\hline \multicolumn{2}{|r|}{ Revenue-neutral tax reforms } \\
\hline Reform_Housebolds & All the above taxes + direct rebates from revenues to households via lump-sum transfers \\
\hline Reform_LAB & $\begin{array}{l}\text { All the above taxes }+ \text { indirect refunding of revenues via a proportional reduction in social } \\
\text { security contributions }\end{array}$ \\
\hline
\end{tabular}

green taxes lead to substantial reductions in $\mathrm{CO}_{2}, \mathrm{NO}_{\mathrm{X}}$ and $\mathrm{SO}_{2}$ emissions. Not surprisingly, policies to combat climate change and air pollution are closely linked, as in both cases the bulk of emissions originate from the same source, i.e. the combustion of fossil fuels. If all the taxes proposed are introduced jointly (Tax_All) $\mathrm{CO}_{2}$ emissions are cut by $10 \%, \mathrm{NO}_{\mathrm{X}}$ emissions by $13 \%$ and $\mathrm{SO}_{2}$ emissions by $20 \%$ respectively. Furthermore, we see that the environmental effectiveness of the tax reform is hardly affected by our revenue recycling options. Direct rebates via transfers to households and indirect refunds via reductions in social contributions lead to almost identical decreases in emissions.

Figure 2 shows the change in GDP and the unemployment rate. ${ }^{14}$ Additional environmental taxes adversely affect economic productivity by limiting the use of fuels in production and consumption. The joint application of all the taxes (Tax_All) has a maximum impact on GDP of less than $0.6 \%$ with $\mathrm{CO}_{2}$ applied to a relatively large base being the largest single contributor.

Revenue recycling (compared to the default of higher public spending) alleviate the adverse GDP impacts to different degrees. As expected the positive revenue recycling effect is less pronounced with lump-sum rebates to households (Reform_Households) compared to the reduction of other pre-existing tax distortions. We see that GDP only decreases by $0.12 \%$ with reductions in distortionary social contributions (Reform_LAB) indicating a weak double dividend. ${ }^{15}$

Clearly, the GDP accounting does not value the positive environmental effects from emission reductions, which are at the origin of green tax reforms. For example, the World Health Organisation (WHO and OECD 2015) postulates that air pollution in Spain in the year 2010 caused 14,000 early deaths with resulting economic losses being equivalent to $2.5 \%$ of GDP.

\subsection{Distributional effects on household groups}

In the discussion of welfare impacts below it should be kept in mind that the four tax scenarios stand-alone (Tax_CO $\mathrm{CO}_{2}$, Tax_NO $\mathrm{NO}_{X}, \mathrm{SO}_{2}$, Tax_Fuel and Tax_All) focus on the incidence of public revenue raising whereas the comprehensive tax reforms Reform_Households and Reform_LAB refer to revenue-neutral policy reforms. In the former case, the level of public good provision will increase with higher public revenues and we do not include potential benefits at

14. In the base-year 2014, the unemployment rate in Spain amounted to $24 \%$.

15. According to Goulder (1995) "a weak double dividend claim is that returning tax revenues through cuts in distortionary taxes leads to cost savings relative to the case where revenues are returned lump sum. The stronger versions contend that revenue-neutral swaps of environmental taxes for ordinary distortionary taxes involve zero or negative gross costs." 


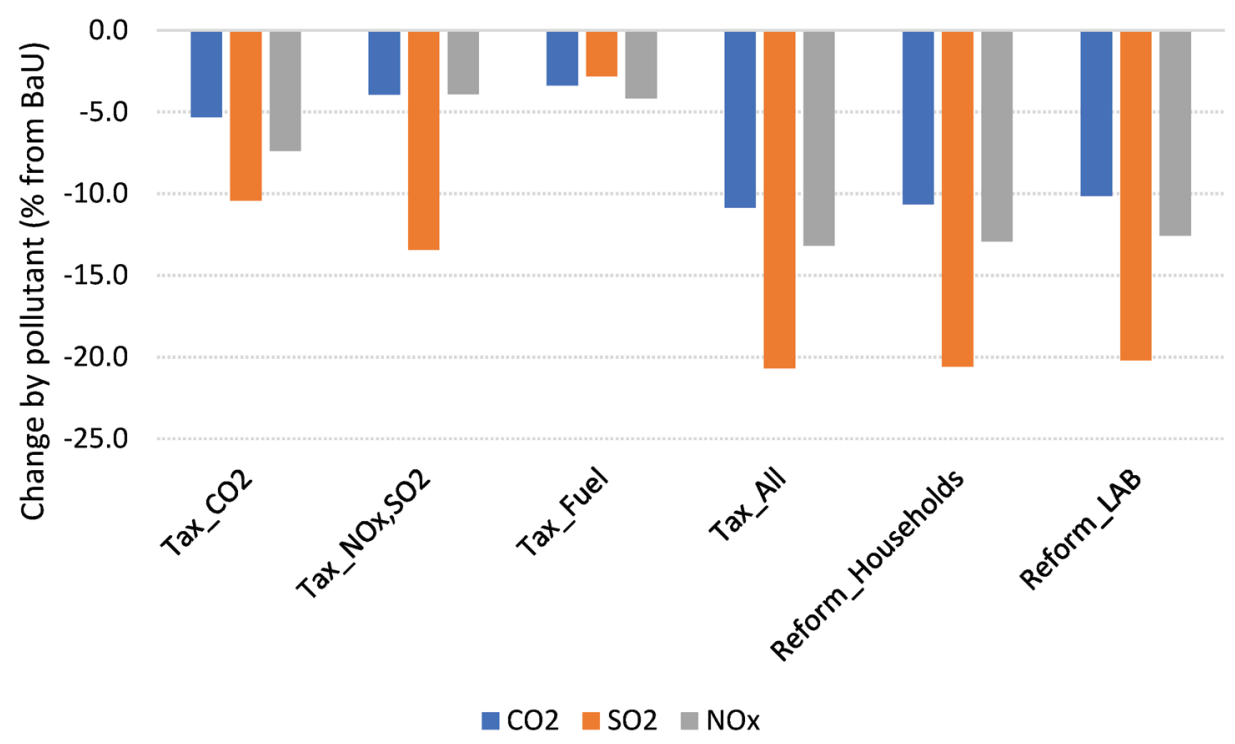

FIGURE 1

Emission impacts (\% from BaU).

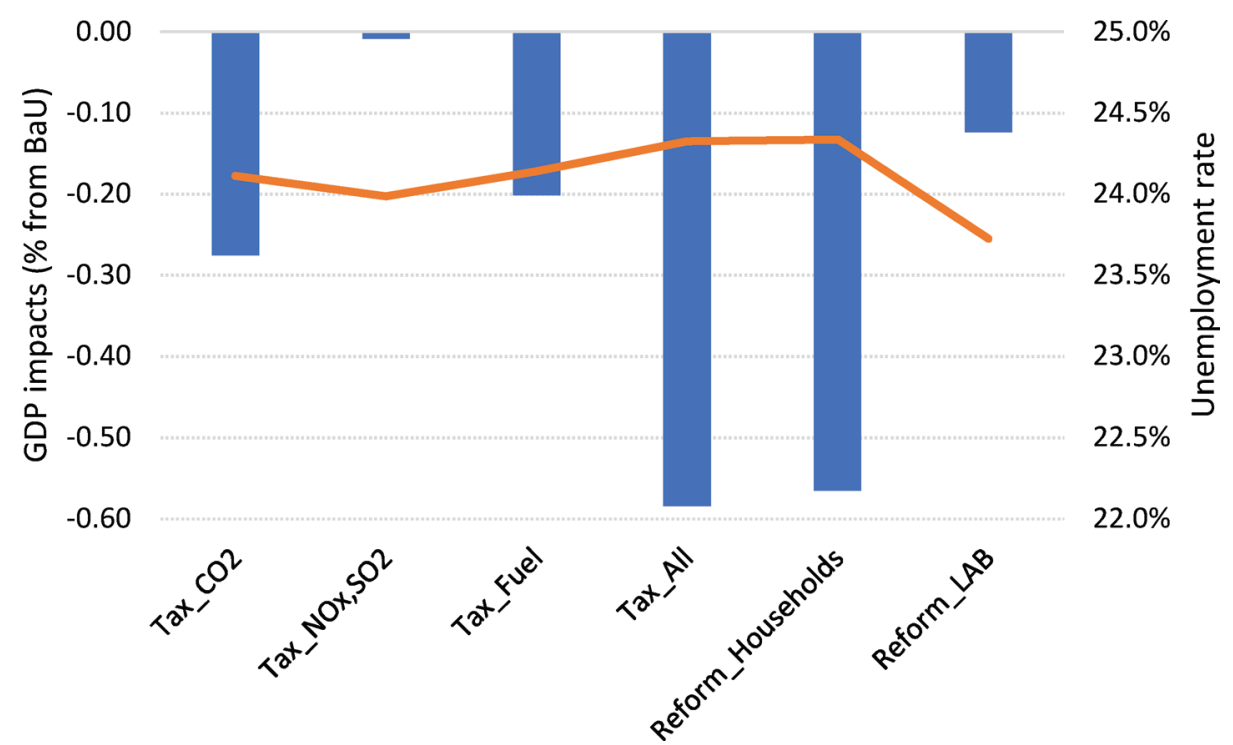

FIGURE 2

GDP impacts (\% from $\mathrm{BaU})$ and unemployment.

the individual household level from this. ${ }^{16}$ In the latter case, the provision of public goods remains at the $\mathrm{BaU}$ level and - with the usual assumption on separability of welfare from public goods and private goods consumption—we can perform coherent welfare analysis across these tax reform packages.

16. Otherwise, there would be the need to have exact information for individual households on their specific valuation of changes in aggregate public good provision. 


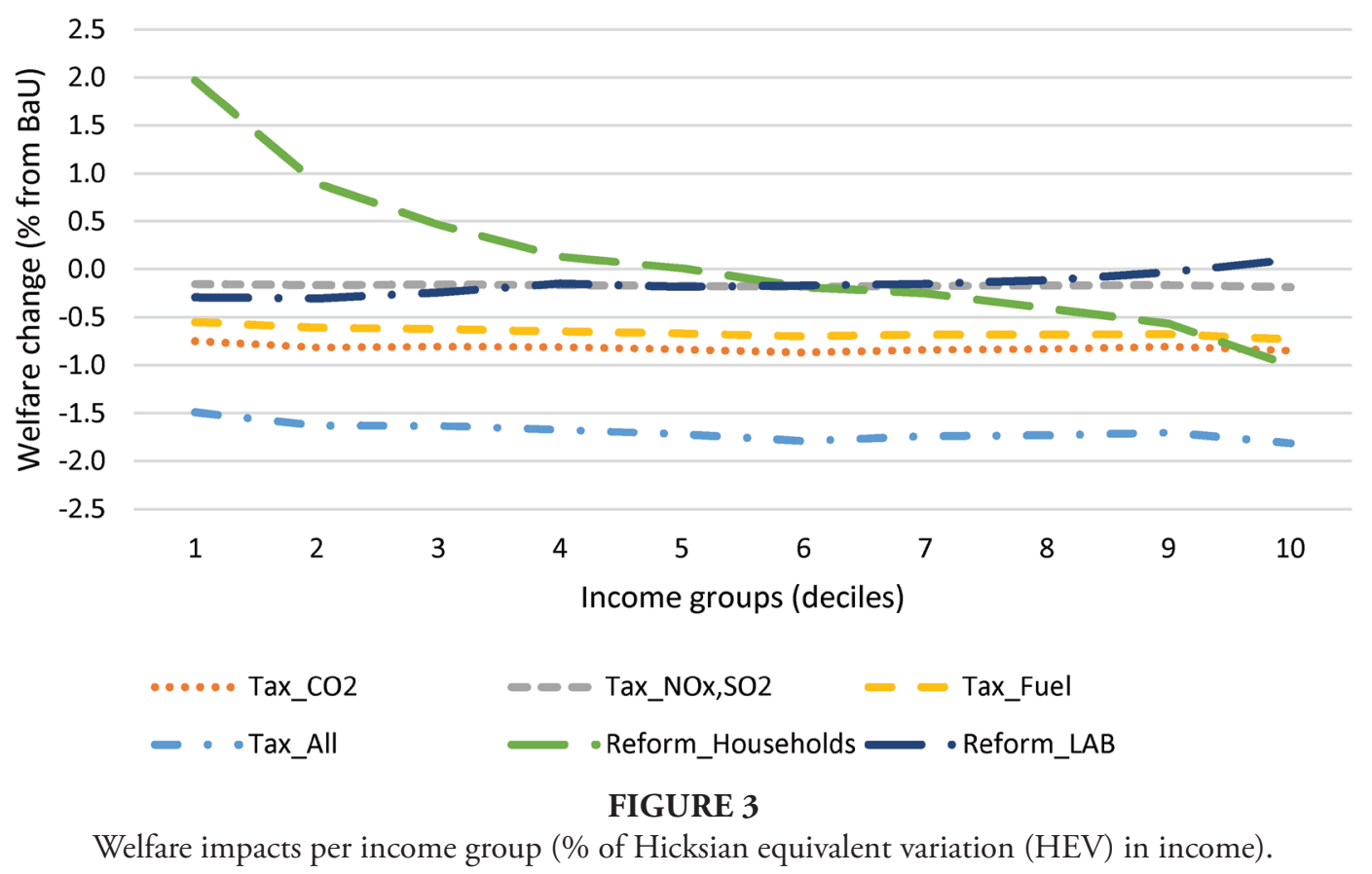

Figure 3 shows the impact on welfare (measured in terms of Hicksian equivalent variation) for different income groups (deciles) - group 1 contains the households with the lowest incomes and group 10 those with the highest.

The stand-alone taxes induce adjustment cost proportional to income so the tax incidence in relative terms is similar across income groups. When all the environmental taxes are levied without any rebate (Tax_All) the welfare cost amounts roughly to $1.5 \%$ across all income groups. Thus, we do not see a regressive impact. The reasoning behind can be traced back to the expenditure patterns of Spanish households as shown in Figure 4.

The taxes introduced affect energy-related goods such as heating, electricity, fuel and transport. When all the taxes are applied together (Tax_All), the price of heating increases by $12 \%$, that of fuel by $10 \%$, that of electricity by $1 \%$ and that of transport by $0.5 \%$. Low-income households spend a larger proportion of their income on heating and electricity (around 4\% of their total spending), but the regressive effect of these taxes is offset by the much higher proportion of spending on fuel and transport by higher-income households (around 9\%).

We furthermore see from Figure 3 that the green tax reform becomes progressive when additional revenues are rebated directly to households. Note that while the rebate (roughly $400 €)$ is identical per household, its welfare impact across household types is quite different. For the poorest households (1st decile), a pay-check of $€ 400$ constitutes a marked increase in disposable income, given that in the 1st decile average annual income is $€ 16,000$. For the wealthiest households (10th decile) the transfer is rather negligible, given that their average annual income is $€ 75,000$. In the Reform_Households scenario, most low-income households are in fact better off as compared to the $\mathrm{BaU}$. Reductions in social contributions-although preferable to direct rebates in terms of GDP performances - tend to be slightly regressive and thus might be discarded on equity grounds.

The CGE-MS linkage permits to decompose welfare effects by household group into the expenditure and income channels. Figure 5 illustrates this decomposition for five income 


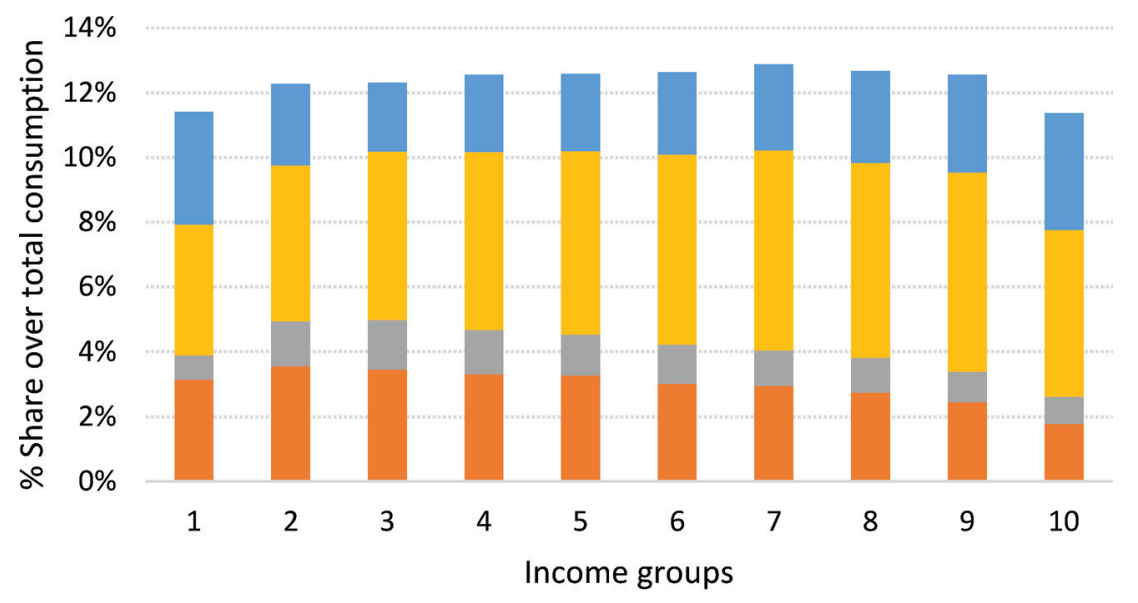

Electricity $\square$ Heating $\square$ Fuels $\square$ Transport

FIGURE 4

Shares of energy consumptions by income group (\% of total consumption).

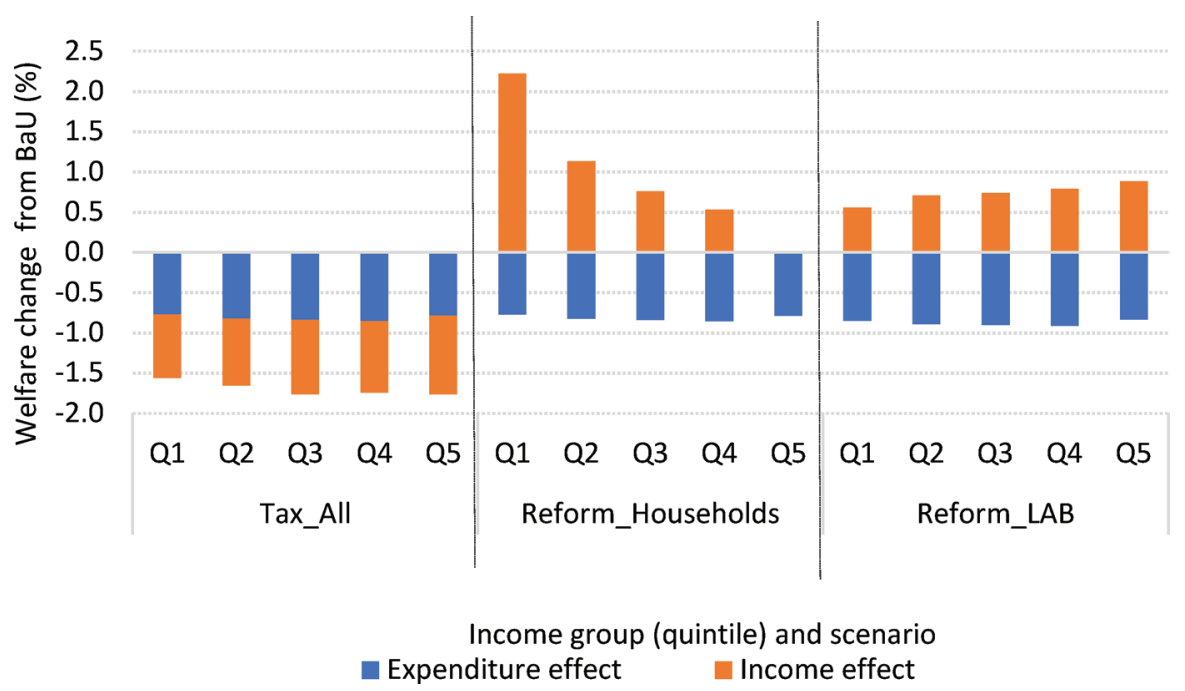

FIGURE 5

Welfare decompositon by expenditure and income (\% of Hicksian equivalent variation (HEV) in income).

groups (income quintiles). The welfare effect of the environmental taxes channeled through expenditures tends to be proportional. Likewise, the welfare effect of the taxes channeled through income is rather proportional. With direct rebates in Reform_Households income-related welfare impacts get positive and progressive. With reductions in social contributions (Reform_LAB), the positive income impacts are stronger for the high-income group than for low-income groups yielding a regressive effect. Table 2 provides further insights into the differential impacts on income sources. Tax_All involves negative income effects across all sources, especially on capital and transfers. The poorest households have net benefits from transfers whereas the middle and upper classes are net transfer donors. Thus, a decrease in transfers en- 
TABLE 2

Income sources impacts (\%) from $\mathrm{BaU}$.

\begin{tabular}{lccc}
\hline & Tax_All & Reform_Households & Reform_LAB \\
\hline Capital & -2.10 & -2.08 & -0.72 \\
Labour & -0.13 & -0.14 & 0.12 \\
Transfer & -0.78 & -0.78 & -0.83 \\
\hline
\end{tabular}

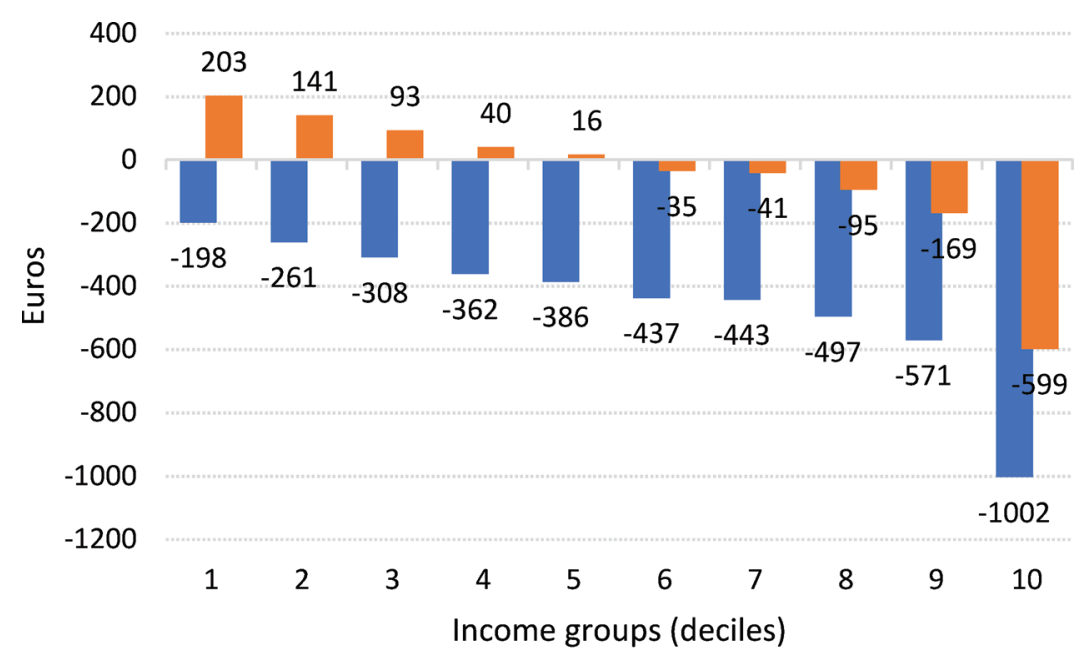

- Cost of the reform Net Benefit/cost

\section{FIGURE 6}

Cost and benefits per household (in Euros).

tails losses for the poorest households and welfare gains for the richest. Labor income is more important for low- and middle-income groups, whereas capital income is more important for high-income groups. Hence, the capital losses compensate the possible regressive effects when all the taxes are introduced (Tax_All). Under Reform_Households the tax rebates to households make the green tax reform progressive.

The progressiveness of direct rebates is also evident from Figure 6, which shows the impact of the reform before (Tax_All_-cost in blue bars) and after-tax revenues are rebated to households (Reform_Households_-net incidence after transfers in orange bars). In the first five deciles the money transfers offset the cost of the environmental tax reform, with the benefits being largest for the poorest households that receive an average net benefit of $€ 203$ (note the richest ones face a net cost of $€ 599$ ).

Figure 7 reports the cost of additional green taxes and the net benefit after rebating for households below the poverty line as compared to households that are not at risk of poverty. ${ }^{17}$ We see that environmental taxes cum direct rebates make vulnerable households better off and thereby can help to mitigate poverty in Spain.

As can be seen from Figure 8, the welfare cost of taxation is larger than 1\% (Tax_All) for most households in the middle- and high-income groups. Direct tax rebates (Reform_House-

17. The poverty line is defined as $60 \%$ of the median household income. Households below that line can be considered as being at risk of poverty. Here, we place the line at $€ 16000$ per annum per household. 


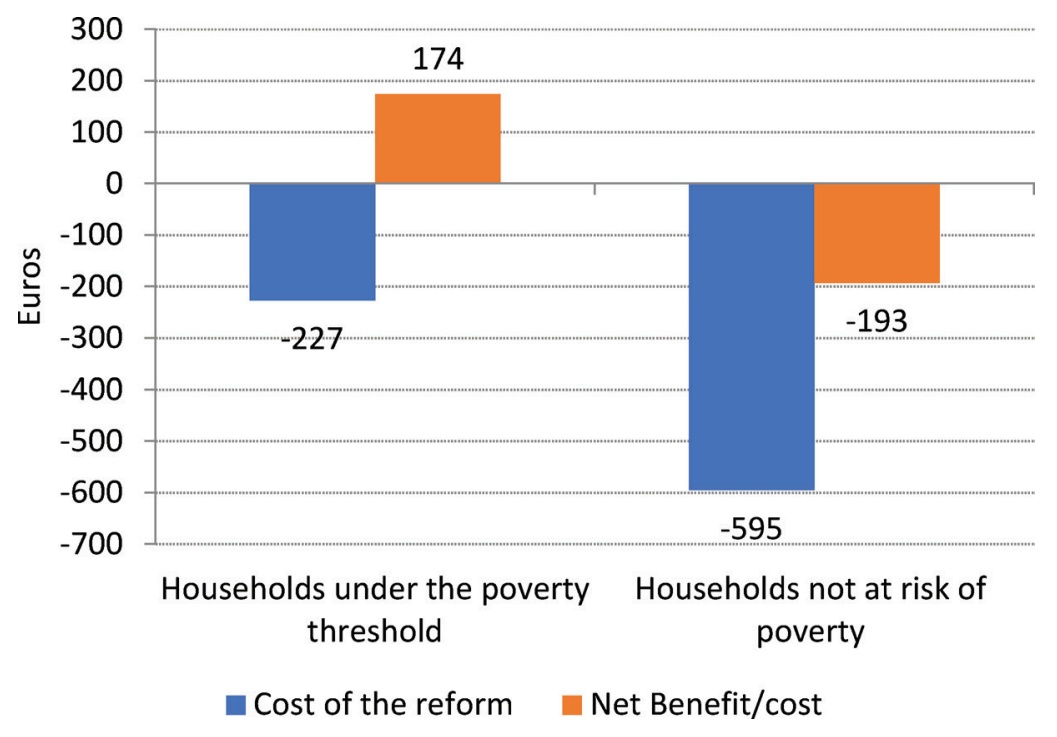

FIGURE 7

Cost and net benefits for households below and above the poverty threshold (in Euros).

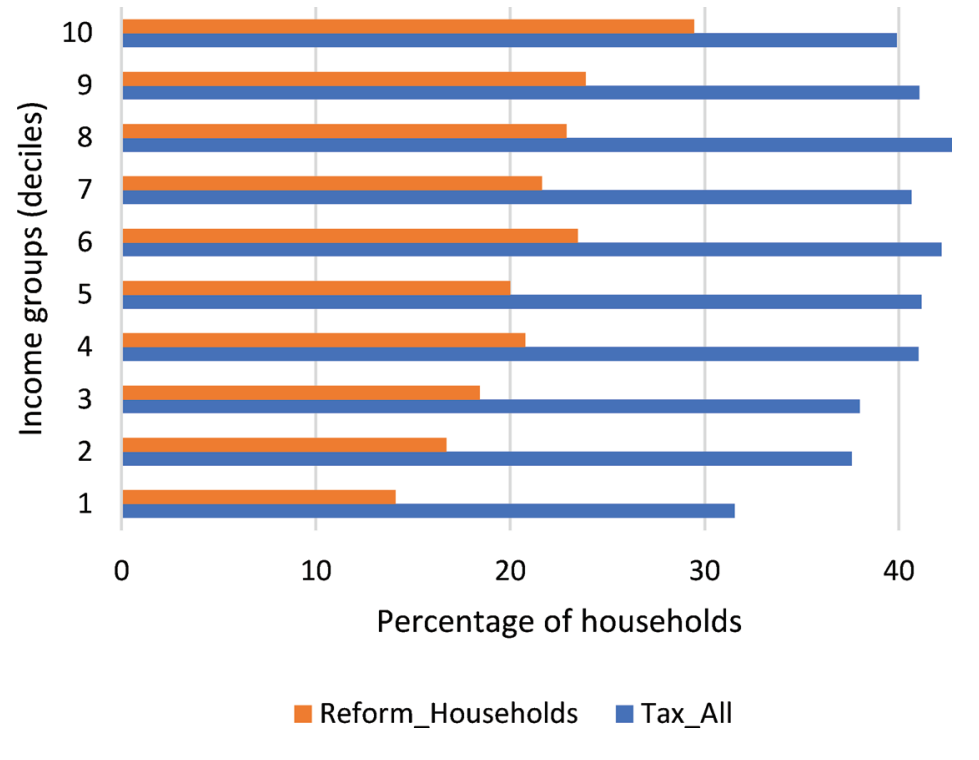

FIGURE 8

Percentage of households with loss larger than $1 \%$, by income deciles.

holds) considerably reduce the cost borne by households and increases the progressiveness of the environmental tax reform.

Figure 9 provides further information on the incidence of environmental tax reforms for seven household types: childless couples, couples with one child, couples with more than one child, single-parent households, childless single persons, retired couples and retirees living alone.

The impacts of green tax reforms differ widely across these household types. Couples with and without children are most negatively affected, while those who benefit the most from the 


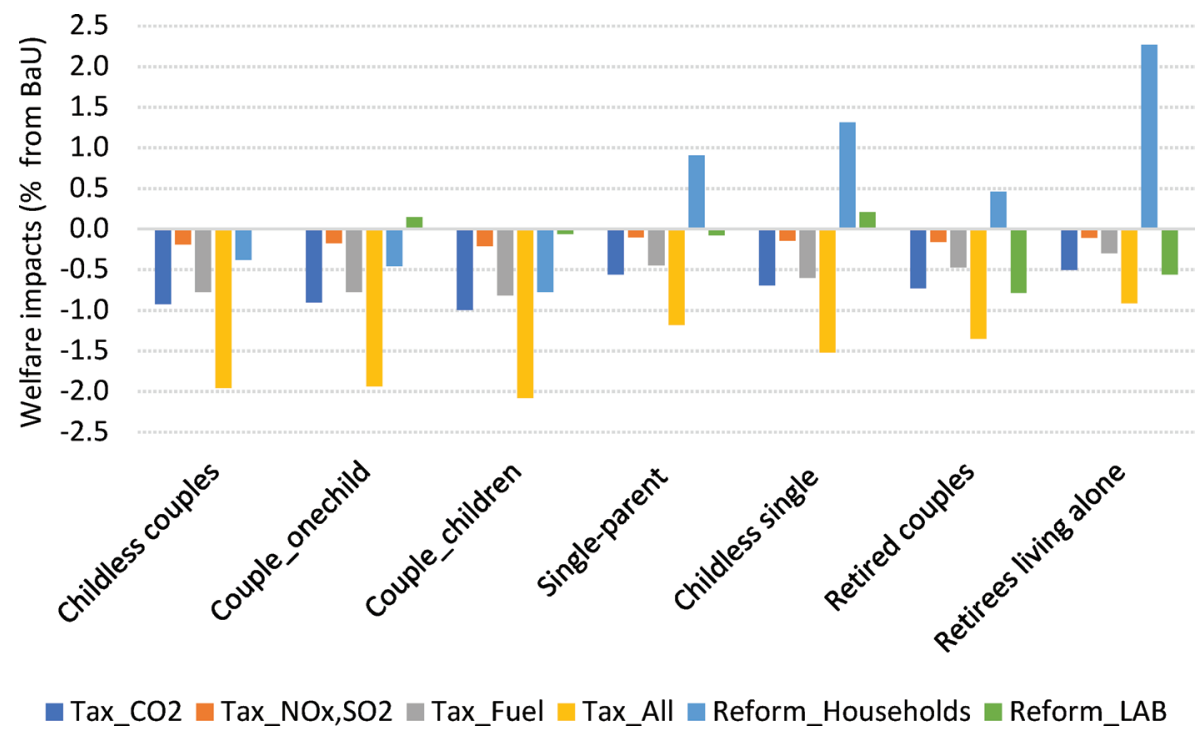

FIGURE 9

Welfare impacts per household type (in \% of Hicksian equivalent variation (HEV) in income).

reform are households made up of retirees. There is a close correlation between the impacts per household type and household income. This explains why couples with and without children are least favored by the tax reform package: they tend to belong to the higher income brackets. Households made up of retirees tend to belong to lower income brackets, so the rebates increase their welfare. Single-parent and childless single-person households deserve a separate mention. The former tends to belong to relatively low-income brackets, but the impact of the rebate is not so positive for them due to their large expenditures for energy-/emission intensive goods whose prices go up most, i.e. heating, electricity and transport. Single-person households tend to belong to medium-to-high income brackets, but their expenditures for energy/ emission-intensive goods is relatively low-the cost of taxes for them are thus rather modest and in total they benefit when taxes get rebated lump-sum. Households that include retirees make up a substantial part of the population ( $28 \%$ of the total household population) and have great preponderance in political decision-making. If they are better off under the tax reform proposed, this could significantly affect its acceptability and viability.

\subsection{Social welfare analysis}

In order to assess the aggregate incidence of policy reforms across households and obtain insights into potential equity-efficiency trade-offs, we adopt the metric of a social welfare function. We use the social welfare (SW) function established by Atkinson (1970):

$$
\mathrm{SW}=\frac{1}{N} \sum_{h} \frac{Y_{h}^{1-\varepsilon}}{1-\varepsilon}
$$

where:

$Y_{h}$ represents the real income level of household $h$,

$\varepsilon$ is the inequality-aversion coefficient and

$N$ denotes the population. 
Following Böhringer et al. (2012), in our analysis, we present welfare changes as changes in the equally distributed equivalent income $\left(\mathrm{Y}_{\text {ede }}\right)$ as defined by Atkinson (1970):

$$
\begin{gathered}
\mathrm{Y}_{\text {ede }}=\left[\frac{1}{N} \sum_{h} Y_{h}^{1-\varepsilon}\right]^{\frac{1}{1-\varepsilon}} \text {, if } \varepsilon \neq 1 \\
\mathrm{Y}_{\text {ede }}=\prod_{h} Y_{h}^{\frac{1}{N}} \text {, if } \varepsilon=1
\end{gathered}
$$

Trade-offs between efficiency and equity across alternative financing scenario are summarized by alternative choices of the inequality-aversion parameter $\varepsilon$. A zero value of $\varepsilon$ corresponds to social preferences where cost distribution across households does not matter, i.e. a utilitarian (Benthamite-labelled "Bentham" in Figure 10 below) perspective on efficiency with utility changes across individual households being perfectly substitutable. On the other extreme, when $\varepsilon$ takes on an infinite value, social preferences take on a Rawlsian perspective (labelled "Rawls" in Figure 10 below), where it is the welfare level of the poorest household that determines social welfare. Figure 10 depicts the social welfare impacts across scenarios. Entries listed in between the two extremes "Bentham" and "Rawls" refer to results based on intermediate values of $\varepsilon$ ranging from zero to infinity.

When inequality aversion is low, the social welfare effects align with the ranking by GDP (see Figure 2). As we abstain in our welfare analysis from quantifying the money-metric utility from a better environment, it is the scenario Tax_All with all the new environmental taxes being implemented that performs the worse in welfare terms from an efficiency perspective. Direct rebates to households (Reform_Households) reduce efficiency cost slightly, but not as much as if revenues were returned by reducing other distortionary taxes, as is the case for Reform_LAB. In fact, the outcome of Reform_LAB provides a double dividend, given that the tax

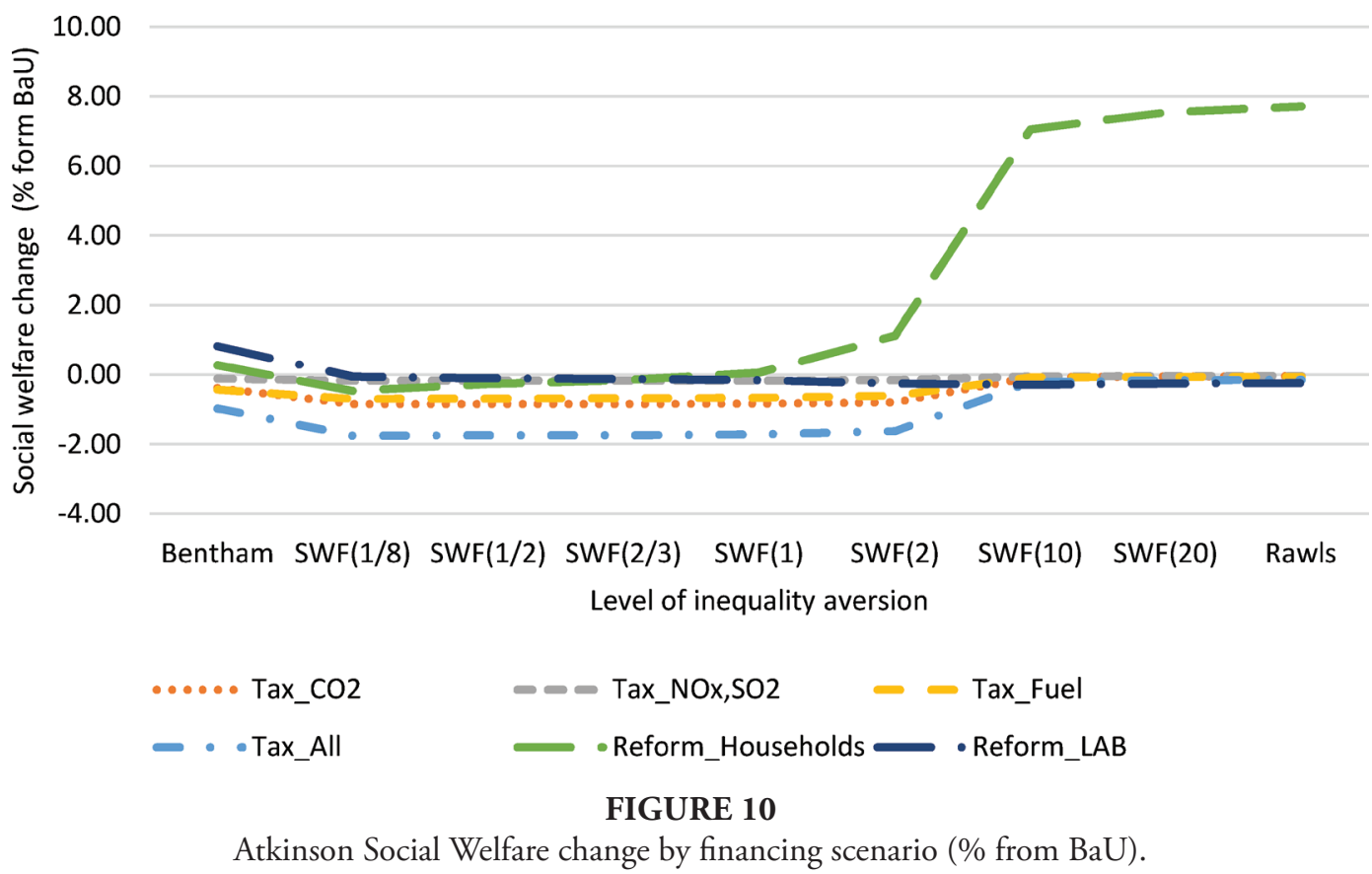


reform not only enhances the efficiency of the tax system but also brings about improvements in environmental quality. As inequality aversion becomes more important, Reform_Households performs much better than all the other scenarios and provides gross social welfare gains. The other scenarios are relatively insensitive to the choice of inequality aversion, indicating that, even if no refund mechanism applies, environmental taxes tend to be proportional.

\section{* 5. CONCLUSIONS}

As many other OECD countries, Spain faces the challenge of mitigating climate change and protecting the local environments in a sustainable manner. To meet such challenges through appropriate policy regulations, the economic discipline has pushed the concept of an environmental tax reform over the last decades. Such tax reforms have been shown to achieve at least a weak double dividend, i.e. effectively reduce environmental pressures while reducing the overall cost of economic adjustments to stricter environmental regulations via revenue recycling. Prominent among proposals for revenue recycling are revenue-neutral reductions in those pre-existing taxes which are most distortionary thereby enhancing the efficiency of the tax system. However, while these proposals are attractive from an economic efficiency perspective, they might neglect important distributional consequences across heterogeneous households. More specifically, there could be trade-offs between equity and efficiency as the most efficient revenue-recycling option lead to a regressive outcome. Concerns on regressive impacts explain in part the reluctance of Spanish policy makers to go ahead with more ambitious green tax reforms. The obvious policy dilemma for broader social acceptability is to find a tax policy design which on the one hand is environmentally effective and on the other hand appeals as fair without inflicting (too much on) overall economic performance.

In this paper, we show that concerns on the regressivity of additional environmental taxes in Spain can be muted through lump-sum transfers of green tax revenues. More specifically, we suggest a green tax reform where revenues from environmental taxes on vehicle fuels, air pollutants and $\mathrm{CO}_{2}$ emissions in non-ETS sectors are rebated to households on an equal-percapita basis. Such a tax reform would have a progressive impact while leading to substantial reductions in emissions of $\mathrm{CO}_{2}, \mathrm{NO}_{\mathrm{X}}$, and $\mathrm{SO}_{2}$. Moreover-provided that societal preferences in Spain are rather egalitarian-the reform would improve on gross social welfare without an equity-efficiency trade-off to the current situation. In terms of practical policy appeal, the reform stands out for a simple design with only few additional environmental taxes and a clearcut uniform rebate mechanism. The latter could be refined towards differentiated rebates for more specific protection of vulnerable socio-economic groups.

The quantitative impact assessment builds on an integrated framework combining a multi-sector computable general equilibrium model of the Spanish economy with a microsimulation model of Spanish households. Our approach stands out for its comprehensive and consistent coverage of important economic drivers for the incidence appraisal of policy interventions. Nonetheless, there are various avenues for extensions to foster and deepen policy-relevant insights. A more detailed representation of the pre-existing Spanish tax and transfer system for various household groups can contribute to the robustness of the simulation results; likewise, the explicit representation of initial regulatory "green" measures such as energy efficiency standards or quotas for renewable energy would be desirable to the extent that they strongly overlap and interact with environmental taxes. Our current model system is static- to track economic adjustment along the transition path as well as long-run effects on savings 
and investment would call for an explicit dynamic (intertemporal) time treatment. Likewise, the incorporation of (endogenous) technological change induced by environmental taxation and alternative revenue recycling options can have non-negligible impacts on the incidence of green tax reforms. We plan to address such issues in future research.

\section{References}

Anger, N., Böhringer, C. and Löschel, A. (2010). "Paying the piper and calling the tune? A meta-regression analysis of the double-dividend hypothesis," Ecological Economics 69: 1495-1502. https://doi.org/10.1016/j. ecolecon.2010.02.003.

Armington, P.S. (1969). "A theory of demand for products distinguished by place of production," International Monetary Fund Staff Papers 16 (1): 159-176. https://doi.org/10.2307/3866403.

Atkinson, A.B. (1970). "On the measurement of inequality." J. Econ. Theory 2, 244-263. https://doi. org/10.1016/0022-0531(70)90039-6.

Blanchflower, D.G. and Oswald, A.J. (1995). "An introduction to the wage curve." Journal of Economic Perspectives 9 (3): 153-167. https://doi.org/10.1257/jep.9.3.153.

Bovenberg, A.L. (1999). “Green tax reforms and the double dividend: An updated reader's guide." International Tax and Public Finance, 6, 421-424. https://doi.org/10.1023/A:1008715920337.

Böhringer, C., Carbone, J.C. and Rutherford, T.F. (2012). "Unilateral Climate Policy Design: Efficiency and Equity Implications of Alternative Instruments to Reduce Carbon Leakage." Energy Economics 34, 208-217. https:// doi.org/10.1016/j.eneco.2012.09.011.

Böhringer, C., Müller, A. and Schneider, J. (2015). “Carbon Tariffs Revisited," Journal of the Association of Environmental and Resource Economists, 2 (4). https://doi.org/10.1086/683607.

Deaton, A. and Muellbauer, J. (1980). "An almost Ideal Demand System." American Economic Review, 70, 312-326.

EEA (2011). European Environment Agency. Environmental tax reform in Europe: implications for income distribution. Technical report No 16/2011.

EC (2011). Proposal for a Council Directive amending Directive 2003/96/CE restructuring the Community framework for the taxation of energy products and electricity. European Commission, Brussels.

Eurostat (2017). Environmental tax statistics. 2017. http://ec.europa.eu/eurostat/statistics-explained/index.php/ Environmental_tax_statistics.

Eurostat (2018). Energy statistics. 2018. https:/ec.europa.eu/eurostat/statistics-explained/index.php/Energy.

Gago, A. and Labandeira, X. (2014). La imposición ambiental como opción para España. Papeles de Economía Española.

Gago, A, Labandeira, X. and López-Otero, X. (2014). "A Panorama on Energy Taxes and Green Tax Reforms." Hacienda Pública Española, IEF, vol. 208(1), pages 145-190, March. https://doi.org/10.7866/HPE-RPE.14.1.5.

González-Eguino, M. (2011). "The importance of the design of market-based instruments for CO2 mitigation: an AGE analysis for Spain.” Ecological Economics, 70, 2292-2302. https://doi.org/10.1016/j.ecolecon.2011.05.023.

Goulder, L.H. (1995). Environmental Taxation and the double dividend: A reader's guide. Int. Tax Public Finan. 2, 157-184. https://doi.org/10.1007/BF00877495.

Graham, P., Thorpe, S. and Hogan, L. (1999). "Non-competitive market behaviour in the international coking coal market.” Energy Economics, 21 (3), 195-212. https://doi.org/10.1016/S0140-9883(99)00006-7.

Holland, M., Pye, S., Watkiss, P., Droste-Franke, B. and Bickel, P. (2005). Damages per tonne emission of PM2,5, NH3, SO2, NOx and VOCs from each EU25 Member State (excluding Cyprus) and surrounding seas, March 2005 $A E A, \mathrm{UK}$.

INE (2018a). Contabilidad Nacional de España. Base 2002. Marco input-output. Tabla Input-Output, Año 2007. Instituto Nacional de Estadística. www.ine.es

INE (2018b). Encuesta continua de presupuestos familiares, base 1997. Instituto Nacional de Estadística. www.ine.es. Informe Lagares (2014). Informe de la Comisión de Expertos para la Reforma del Sistema Tributario Español ("Informe Lagares"). Madrid.

IEA (2015). Energy Policies of IEA Countries: Spain 2015 Review, OECD/IEA, International Energy Agency, Paris. IMF (2013). Energy subsidy reform: lessons and implications. International Monetary Fund, Washington D.C.

Kiuila, O. and Sleszynski, L. (2003). "Expected effects of the ecological tax reform for the Polish economy." Ecological Economics, 46: 103-120. https://doi.org/10.1016/S0921-8009(03)00124-1. 
Koesler, S. and Schymura, M. (2015). "Substitution Elasticities in a Constant Elasticity of Substitution Framework-Empirical Estimates Using Nonlinear Least Squares.” Economic Systems Research 27, 101-121. https:// doi.org/10.1080/09535314.2014.926266.

Kosonen, K. (2012). "Regressivity of environmental taxation: myth or reality?” J. Milne, M.S. Andersen (eds.), Handbook of Research on Environmental Taxation, Cheltenham: Edward Elgar Publishing, 161-174. https://doi. org /10.4337/9781781952146.00018.

Krichene, N. (2002). "World crude oil and natural gas: a demand and supply model." Energy Economics, 24 (6), 557-576. https://doi.org/10.1016/S0140-9883(02)00061-0.

Labandeira, X. and Labeaga, J. (1999). “Combining input-output analysis and micro-simulation to assess the effects of carbon taxation on Spanish households.” Fiscal Studies, 20, 305-320. https://doi.org/10.1111/j.1475-5890.1999. tb00015.x.

Labandeira, X., Labeaga, J.M. and Rodríguez, M. (2004). “Green Tax Reforms in Spain.” European Environment 14, 290-299. https://doi.org/10.1002/eet.361.

Labandeira, X. and Linares, P. (2013). Impuestos energético--ambientales en España, Economics for Energy, Vigo.

Leipprand, A., Gavalyugova, N., Meyer-Ohlendorf, N., Blobel, D. and Persson, A. (2007) Links between the social and environmental pillars of sustainable development, Task 1D: Environmental taxes, Ecologic, September 2007.

Manresa, A. and Sancho, F. (2005). "Implementing a double dividend: recycling ecotaxes towards lower labour taxes," Energ. Policy 33, 1577-1585. https://doi.org/10.1016/j.enpol.2004.01.014.

Markandya, A., Bigano, A. and Prochina, R. (2010). "The Social Cost of Electricity, Scenarios and Policy Implications," Fondazione Eni Enrico Mattei, Milan. https://doi.org/10.4337/9780857937155.

Markandya, A., González-Eguino, M. and Escapa, M. (2013). "From shadow to green: linking environmental fiscal reforms and the informal economy," Energy Economics, 40, 108-118. https://doi.org/10.1016/j.eneco.2013.09.014.

OECD (1995). Climate change, economic instruments and income distribution, Organisation for Economic Cooperation and Development, Paris.

OECD (2015). OECD Environmental Performance Reviews: Spain 2015, OECD Publishing, Paris. DOI: https:// doi.org/10.1787/9789264226883-en.

OECD (2017). Policy Instruments for the Environment, Database 2017, OECD Paris, DOI: http://oe.cd/pine

Pearce, D. (1991). "The role of carbon taxes in adjusting to global warming." Economic Journal 101 (407), 938-948. https://doi.org/10.2307/2233865.

Peter, M., Lückge, H., Iten, R., Trageser, J., Görlach, B., Blobel, D. and Kraemer, R.A. (2007). Erfahrungen mit Energiesteuern in Europa-Lehren für die Schweiz, Infras/Ecologic im Auftrag des Schweizerischen Bundesamtes für Energie (BFE).

Pigou, A.C. (1920). The economics of welfare, Fourth edition (1960) (Macmillan, London) (First edition 1920 and first publication of the fourth edition 1932).

Repetto, R. (1992). Green Fees: How a Tax Shift Can Work for the Environment and the Economy. World Resources Institute, Washington, D.C.

Ringlund, G.B., Rosendahl, K.E. and Skjerpen, T. (2008). "Do oilrig activities react to oil price changes? An empirical investigation.” Energy Economics 30: 371-396. https://doi.org/10.1016/j.eneco.2007.06.002.

Rutherford, T.F. and Tarr, D.G. (2008). "Poverty effects of Russia's WTO accession: Modeling "real" households with endogenous productivity effects." Journal of International Economics, 75(1):131-150. https://doi. org/10.1016/j.jinteco.2007.09.004.

Speck, S. (1999) "Energy and carbon taxes and their distributional implications." Energy Policy, 27, pp. 659-667. https://doi.org/10.1016/S0301-4215(99)00059-2.

Speck, S., Andersen, M.S., Nielsen, H.Ø., Ryelund, A.V. and Smith, C. (2006) The Use of Economic Instruments in Nordic and Baltic Environmental Policy 2001-2005. Nordic Council of Ministers, TemaNord 2006:525. https:// doi.org/10.6027/tn2006-525.

WHO and OECD (2015). Economic cost of the health impact of air pollution in Europe: Clean air, health and wealth, WHO Regional Office for Europe. 
ANNEX A:

ALMOST IDEAL DEMAND SYSTEM, ESTIMATED AS A SEEMINGLY UNRELATED REGRESSION

TABLE A1

Almost Ideal Demand System, estimated as a seemingly unrelated regression, estimates rounded to 3 digits.

\begin{tabular}{lcccccccc}
\hline & & & & & & & \multicolumn{3}{c}{ Education and } \\
& Food & Housing & Fuel & Electricity & Heat & Transport & Leisure & Durables \\
\hline $\ln$ (p_food) & $0.030^{* *}$ & -0.007 & $-0.018^{*}$ & -0.001 & $0.001^{*}$ & 0.014 & $-0.057^{*}$ & -0.011 \\
$\ln$ (p_housing) & -0.007 & $0.176^{*}$ & $-0.012^{*}$ & $0.011^{*}$ & 0.001 & -0.003 & $-0.052^{*}$ & $-0.110^{*}$ \\
$\ln$ (p_fuel) & $-0.018^{*}$ & $-0.012^{*}$ & $0.029^{*}$ & $-0.001^{*}$ & $-0.001^{*}$ & $-0.014^{*}$ & $-0.017^{*}$ & $0.037^{*}$ \\
$\ln$ (p_electricity) & -0.001 & $0.011^{*}$ & $-0.001^{*}$ & $0.015^{*}$ & $-0.001^{*}$ & $-0.004^{*}$ & $-0.008^{*}$ & $-0.007^{*}$ \\
$\ln$ (p_heat) & $0.001^{*}$ & 0.001 & $-0.001^{*}$ & $-0.001^{*}$ & $0.006^{*}$ & $-0.001^{*}$ & $-0.003^{*}$ & $-0.002^{*}$ \\
$\ln$ (p_transport) & 0.014 & -0.004 & $-0.014^{*}$ & $-0.003^{*}$ & $-0.001^{*}$ & $0.042^{*}$ & 0.013 & -0.017 \\
$\ln$ (p_leisure \& & $-0.057^{*}$ & $-0.052^{*}$ & $-0.017^{*}$ & $-0.008^{*}$ & $-0.002^{*}$ & 0.013 & $0.131^{*}$ & -0.014 \\
$\quad$ & & & & & & & & \\
$\ln$ education) & & & & & & -0.015 & $0.097^{*}$ \\
$\ln$ (p_durables) & -0.011 & $-0.110^{*}$ & $0.037^{*}$ & $-0.007^{*}$ & $-0.002^{*}$ & -0.017 & -0.015 & $0.028^{* *}$ \\
\hline
\end{tabular}

* Statistically significant at the $5 \%$ level.

** Statistically significant at the $10 \%$ level 